Open Access

\title{
Exploring the socio-cultural challenges of food processing women entrepreneurs in IRINGA, TANZANIA and strategies used to tackle them
}

\author{
Alsen Florian Kapinga ${ }^{1 *}$ and Calkin Suero Montero ${ }^{2}$
}

* Correspondence:

a.kapinga@cbe.ac.tz;

kamingila@yahoo.com

${ }^{1}$ College of Business Education

(CBE), Dar es Salaam, Tanzania

Full list of author information is

available at the end of the article

\begin{abstract}
Women entrepreneurs have significant contributions to the economies of sub-Saharan Africa. However, women in this region are facing a shocking array of challenges in their business environment. This paper examines the challenges facing women entrepreneurs in the food processing industry in Iringa, Tanzania. The study employs interviews and focus group discussions in collecting data and utilizes content analysis for interpreting findings. The findings indicate that these women entrepreneurs face problems of lack of access to markets, unequal social responsibility and lack of enough capital. Our findings also show that women entrepreneurs in the food processing business of the region employ an array of transversal strategies in order tackle and mitigate the socio-cultural challenges, including the creation of economic groups and entrepreneurship clubs. Our work sheds light on the issues that women entrepreneurs in the food processing industry struggle with in Iringa. Furthermore, we present the general and transversal strategies that they use in order to mitigate the problem and finally put forward the use of mobile technology as a transversal tool.
\end{abstract}

Keywords: Women entrepreneurs, Sub-Saharan Africa, Institutional theory, Feminist theory

\section{Background}

Women entrepreneurs account for a substantial majority of small-scale entrepreneurs in Sub-Saharan Africa (SSA) (Belwal et al. 2012). Entrepreneurship has increasingly attracted the governments' and policy making institution's attention in recent years. According to Jamali (2009), the attention has been drawn in light of concrete evidence of the importance of new business creation for economic growth and development. Women entrepreneurs' businesses are best described as micro or small-scale enterprises ((Belwal et al. 2012; Siddiqui 2012). Through their enterprises, women entrepreneurs empower themselves and contribute to the development of the society at large. Even if the majority of women who operate enterprises have less than three employees, based on the nature of the enterprises, women have the potential to raise their business' employment and create job opportunities for many unemployed people (Wasihun and Paul 2010). Hence, it is

(c) The Author(s). 2017 Open Access This article is distributed under the terms of the Creative Commons Attribution 4.0 International License (http://creativecommons.org/licenses/by/4.0/), which permits unrestricted use, distribution, and reproduction in any medium, provided you give appropriate credit to the original author(s) and the source, provide a link to the Creative Commons license, and indicate if changes were made. 
important to devote attention to issues that constrain women entrepreneurs from carrying out their business.

Despite the fact that women entrepreneurs contribute to economic growth, several issues have been identified to affect the advance of business for women entrepreneurs in SSA, including market access, initial capital, unequal distribution of responsibility, and skills in business (Rutashobya and Nchimbi 1999; Magesa et al. 2013). Furthermore, literature indicates that women entrepreneurs face more socio-cultural challenges compared to their male counterparts (Gichuki et al. 2014; Brush et al. 2009). In this context, socio-cultural challenges are issues related to cultural expectations (e.g., values, attitudes, gender roles, etc.) and societal structures (e.g., family, reference groups or networks, status in society, etc.) that affect the development of women entrepreneurs. In the developing economies, women confront barriers to success due to negative social attitudes arising from intensely rooted, prejudiced cultural values, attitudes, practices, and traditions of male-controlled cultures (Woldie and Adersua 2004). In SSA, the socio-cultural challenges that affect women during the development of their businesses are embedded in patriarchal ideology that undervalues women's efforts and ability to excel in their enterprises (Magesa et al. 2013). According to Singh and Belwal (2008), women face challenges in securing finances for establishing and running SMEs and entrepreneurial and management competence. They also lack exposure and encounter challenges in finding suitable markets and distribution networks. In addition, women have limited opportunities for promotion and participation. The male-controlled family arrangements demonstrate the power given to the father and the elder sons. Women do not have power to influence decisions that favor their wellbeing, hence lack of power balance between males and females. Given the unfavorable socio-cultural setting for women in most SSA, social empowerment of women requires transformation in terms of division of labor, as well as a change in the prevalent ideologies about the roles and responsibilities of women and men (Munyua and Mureithi 2008).

Although women entrepreneurs have been recognized as an important agent of economic development in SSA (Woldie and Adersua 2004) the socio-cultural conditions that restrict women from developing their business in the rural areas of Tanzania are yet to be explored. Agriculture has been identified as a key provider of employment and livelihood in the rural areas of the country and a priority area for strategic intervention, under the Tanzania Development Vision (TDV) 2025 and other government policies (ASSP 2014). According to the Tanzania Ministry of Agriculture and Food Security Annual Report, the agriculture sector in Tanzania contributes $28.9 \%$ of the national GDP and provides 75\% of the total country labor force as per 2015 (The United Republic of Tanzania, URT 2015). Furthermore, the agriculture sector is reported to be linked with non-farming activities, through an association with agro-processing of farmed products, and women constitute the main source of labor force of the agriculture sector (Mmasa 2013).

Several studies have investigated the socio-cultural challenges facing women entrepreneurs in Tanzania. For example, Majenga and Mashenene (2015) revealed that there is a direct relationship between socio-cultural factors (SCF), such as interference and lack of support from husbands, and poor financial performance (FP) of women small and medium enterprises in Tanzania (see also Maziku et al. 2014). However, the study by Majenga and Mashenene focused mainly on women entrepreneurs from the urban 
area of Dodoma, with a small proportion of entrepreneurs from Chamwino rural area. Our study is different from those of Majenga and Mashenene (2015) and Maziku et al. (2014) because we focus on challenges facing women entrepreneurs in the food processing industry in the rural area of Iringa, a prime agriculture area of Tanzania. Since women are the main labor force in the agriculture sector, the socio-cultural issues related to the women entrepreneurs need to be explored as they have a significant impact on the national economic growth. Furthermore, our work goes beyond the identification of the socio-cultural issues, to also present and discuss the general transversal strategies that women entrepreneurs of the region employ to mitigate the problems they face.

Therefore, in the context Tanzania as a case study, we use institutional and feminist theories to explore the socio-cultural conditions that tend to curtail women entrepreneurs' success in the food processing chain. Therefore, the main objective of this study is to explore the socio-cultural challenges facing women entrepreneurs in Iringa southern highland region of Tanzania and strategies used to overcome them. The research questions included the following:

- What are the motivating factors for women to engage in entrepreneurial activities in the food processing business in Iringa?

- What are the socio-cultural challenges that affect the business activities of women entrepreneurs in the food processing industry of Iringa?

- How can these challenges be mitigated or addressed in order to promote sustainable growth of the region and the empowerment of women in the society?

This study is particularly importat as it adds litarature to the existing body of knowledge about the fundamental influence of institutional and feminist perspectives in improving women entrepreneurial activites in emerging SSA economies. The study also advocates the use of easily accessible mobilie technology as a transversal tool for empowerment.

\section{Theoretical perspectives \\ The concept of entrepreneurship}

According to Kuratko (2011), entrepreneurship is defined as a "dynamic process of vision, change, and creation that requires an application of energy and passion towards the creation and implementation of new ideas and creative solution". The essential ingredients of entrepreneurship include the willingness to take calculated risks in terms of time equity, ability to formulate an effective team, creative skills to marshal needed resources, fundamental skills of building a solid business plan and the vision to recognize the opportunity. Entrepreneurship is also seen as a field of business that seeks to understand how opportunities to create something new (e.g. new product or services, new production process or raw materials, new way of organizing technologies) arise and are discovered or created by specific persons, who then use various means to exploit or develop them, thus producing a wide range of effects (Baron 2013). In the same light, entrepreneurship is viewed as the act of mobilizing or employing and organizing the other factors of production while assuming the associated rewards and risks 
(Olomi 2009). In addition, entrepreneurship can also be perceived as the process of creating something new with a value by devoting the necessary time and effort, assuming the accompanying financial, psychic and social risks and receiving rewards of monetary and personal satisfaction and independence (Hisrich and Peters 2002).

In view of this, entrepreneurs may be defined as individuals who bring about an improvement, both for other individuals and for the society as a whole (Gorji and Rahimian 2011). Longenecker et al. (2003) define entrepreneurs as individuals who discover market needs and launch new firms to meet those needs. They are risk takers who provide an impetus for change, innovation and progress in economic life. Therefore, entrepreneurship implies the process of creation and bringing improvements in the community by discovering market requirements and introducing enterprise to meet the demands. Economic growth and productivity improvements lie in the entrepreneurial capacity of an economy (Audretsch et al. 2007). Entrepreneurship does indeed involve the renovation of ideas (recognize or create chances) into something new and concrete through some kind of overt action. In this study, entrepreneurship is perceived as a tool for personal economic growth and empowerment. Entrepreneurship thus contributes to job creation opportunities and higher quality of community life.

\section{Characteristics of women entrepreneurs}

Women entrepreneurs are women who participate in entrepreneurial activities. Women entrepreneurs create new products, processes, and services for the market consumption. Like other entrepreneurs, women entrepreneurs take the risks involved in combining resources together in a unique way so as to take advantage of an opportunity identified in their immediate environment, through the production of goods and services (Okafor and Mordi 2010). Entrepreneurial characteristics are influenced by the availability of infrastructures, training programs, and financial and family support, all of which can help to enhance the personality of entrepreneurs (Okafor and Mordi 2010).

Women entrepreneurs tend to have a number of common characteristics which include creativity and innovation, foresight, imagination, and courage (Mordi et al. 2010; Pines et al. 2010). According to Storey (1994), other entrepreneurial characteristics include previous management experience through family history, functional skills, and relevant business skills. Family members influence the ability to engage in entrepreneurial behavior (Eddleston et al. 2012). Kuratko (2011) suggests that essential features of women entrepreneurs include total commitment, determination and perseverance, drive to achieve and grow, and opportunity and goal orientation. Furthermore, entrepreneurs are characterized by self-efficacy, higher internal locus of control, the need for autonomy, need to achieve, perseverance, the ability to find and explore the opportunity, risk-taking propensity, innovation, ambiguity tolerance and vision (Deakins and Freel 2009; Singal 2009; Olomi 2009). The work of Siddiqui (2012) indicates that entrepreneurial women are capable of contributing value both to the families and to the society, given their strong desire of doing positive things. These characteristics are highly valued for the economic growth and development of emerging economies in SSA. Women entrepreneurs endowed with more of these attributes are more likely to start and succeed in business than those with less (Olomi 2009). 


\section{Socio-cultural environment}

Wetherly and Otter (2011) describe the socio-cultural environment as an environment consisting of everything that is not contained within the economic or political systems. The socio-cultural system is made of a collection of activities and relationships through which people engage in their personal and private lives, including population features, age, ethnicity, religion, values, attitude, lifestyles, and associates. In this study, the socio-cultural environment implies elements that are embedded in the society and affect the performance of women entrepreneurs, either negatively or positively.

In Tanzania, the socio-cultural environment represents a key factor affecting entrepreneurial capabilities of women entrepreneurs (Mashenene et al. 2014). For instance, poor education and training, interference and lack of support from husbands and lack of business information have been found to be critical socio-cultural factors that affect negatively the financial performance of women small and medium enterprises in Tanzania (Majenga and Mashenene 2015). Previous research has shown several sociocultural factors and their relationship with the business development of the women entrepreneurs (Maziku et al. 2014). In our study, a significant milestone has been achieved by exploring not only the socio-cultural issues that affect women entrepreneurs but also revealing the transversal strategies that are used for personal empowerment and problem mitigation.

\section{Institutional theory and women entrepreneurs}

The institutional theory focuses on the process that forms the basis for social norms and behavior. It blends together the cognitive, normative and regulatory structures that provide stability and meaning to social behavior (Scott 2001). The regulative structures of the institutional theory profile consists of laws, regulations, rules and policies which promote a certain type of behavior and restrict others (Vecian and Urbano 2008). The normative structures consists of social values, beliefs and assumptions about human nature and behavior that are shared and carried by an individual (Vecian and Urbano 2008). The cognitive aspects recognize the cognitive structure and social knowledge shared by people in a given society (Scott 2001). In their study, Amine and Staub (2009) argue that institutional theory takes a sociological view of reciprocal interactions between institutions (such as business entities) and society. An institutional theory is considered relevant in this study because it illustrates how socio-cultural challenges from the perspective of regulatory, normative and cognitive structures could affect the development of women entrepreneurs in food processing business in Tanzania. Thus, institutional theory is important in this study as it provides an established framework for the exploration of how social norms and behaviors affect women entrepreneurs' business performance. The intensity of institutional challenges differs across societal structures, hence a need to tackle those challenges from different dimensions to achieve satisfactory solutions.

\section{Feminist theories and women entrepreneurs}

Feminist theories are relevant to this study because they illustrate how women are marginalized in the business environment and economic dialogue. Feminist theories advocate for the understanding of the nature of gender inequality in the society due to patriarchy ideology and using that knowledge to better women's lives. The theories 
reveal where stereotypes and subjective perceptual variables come from and enrich our understanding of how these exert a fundamental influence on women's entrepreneurial tendency and account for much of difference in entrepreneurial activity between the sexes (Jennings and Brush 2013). Socio-cultural norms have contributed to the creation of the unique barrier for women entrepreneurs to access assets, education and gendered activity expectations among the sexes. Jennings and Brush (2013) identify four substantive contributions of feminist theories to the field of women entrepreneurship: i) entrepreneurship is a gendered phenomenon, ii) entrepreneurship is embedded in families, iii) entrepreneurial activity can result from necessity as well as an opportunity, and iv) entrepreneurs pursue goals beyond economic gain. Therefore, the adoption of a feminist approach to the field of entrepreneurship is important in order to better women's lives. This study highlights two feminist theories which are relevant to the entrepreneurship phenomenon:-

Liberal feminism advocates for equal opportunity for women and assume that the removal of institutional and legal barriers will result in women founders achieving equitable entrepreneurial outcomes with male founders (Greer et al. 2003). Liberal feminism advocates that women and men are essentially the same in understanding and copying the world (Kutanis and Bayraktaroglu 2003). In adddition, liberal feminism tends to ignore gender inequality in the society and focus on gender equality (Greer et al. 2003).

Socialist feminism advocates for equality through socialization processes that shape women to be equal but different from men in the way they view the world (Fischer et al. 1993). Culture shapes the way women view their gender role of being entrepreneurs in the society. Socialist feminism suggests that it does not mean women are inferior to men but rather different. Female experiences differ from those of males because of deliberate socialization methods from childhood life that result in fundamental different ways of viewing the world (Fischer et al. 1993). Therefore, gender differences, unequal access to resources, and unequal economic power relations are socially constructed and differ depending on the culture.

In this article, the socio-cultural challenges facing women entrepreneurs are perceived in light of feminist theories in order to broadly explore the relationship.

\section{Methods}

This study was conducted in Iringa region, one of the Regions of Tanzania Mainland located in the Southern Highland of Tanzania. Iringa was chosen because it is among the leading regions in agricultural production and many women entrepreneurs attempt thriving in their business there.

This study employed a qualitative research approach in order to explore the hurdles affecting women entrepreneurs' business in Iringa. This approach has been useful for exploring and understanding the meaning that individuals or groups ascribe to social or human problems (Cresswell 2014). An ethnography research strategy was used to explore socio-cultural phenomena about women entrepreneurs. This strategy is appropriate in contexts where there is a need to gain insights, through observations, about women entrepreneurs in their business context and activities and understand the issues they face from their points of view and perspectives (Saunders et al. 2009, \& 
Denscombe 2013). Ethnography allows for a high level of congruence between concepts and observations as it involves prolonged participation in the social life of the group over a period of time and description of things witnesed first-hand (Denscombe 2013). Ethnography strategy has been the most powerful influence on the transformation of qualitative research into a kind of postmodern research attitude, which is opposed to the more or less codified application of specific method (Flick 2009). Participant observations that lasted for 2 months were used to collect information on food processing, challenges, and how women market their products (Flick 2009). Observations took a considerable amount of time in order to describe group of women entrepreneurs who share the similar socio-cultural challenges in doing business (Gliner et al. 2009).

A purposive sampling technique was used to reach the women who participate in entrepreneurship using the following criteria: a) working in the food processing industry in Iringa, b) having 1 year or more of entrepreneurship experience in their business. Purposive sampling enabled the researchers to choose relevant respondents in order to address the research questions of this study (see Bryman 2012). The participants were recruited through village leaders, church leaders (for the groups operating under the umbrella of the church, such as MATUMAINI group), telephone calls, and direct contacts along the streets where the women entrepreneurs were selling their products. Thirty-seven (37) participants agreed to participate in this study through this recruiting process. Purposive sampling was also used for selecting some key informants such the regional manager of Small Industries Development Organization (SIDO), the manager for "Muungano wa Ujasiliamali Vijijini" (MUVI), ${ }^{1}$ and the head of Social Welfare Department, in Iringa Municipality. These key informants deal with women entrepreneurs' issues from the government perspective. Furthermore, these governmental organizations were included in the study because of their positions as key stakeholders on issues pertaining to women entrepreneurs, since the institutions provide services such as training on food processing, financial record keeping, business plans preparation and loans.

Primary data for the study were collected through in-depth interviews, focus group discussions (FGDs) and observations. The researcher conducted face-to-face interviews with 14 out of the 37 women entrepreneurs who agreed to participate in the study. After obtaining the interviewees consent, the interview conversations were recoded and later on transcribed for analysis. In addition, the researchers conducted three focus group discussions with three groups of women entrepreneurs (i.E. SARA group: seven participants, MATUMAIN group: eight participants; and others: eight participants). This was done in order to explore attitudes and perceptions, feelings and ideas about business challenges. The sessions took one to one and half hours. The researchers also collected data through direct observations (as part of the general ethnography strategy) on the way participants process food products, the processing environment, the packaging of the products and machines used, and how they accessed market information for their final products. Through observations, the researchers gained insights on the challenges the participants face in undertaking their entrepreneurial activities. Specifically, the observations focused on the processing of various food products, including tomato. For instance in the tomato chain, the observations were on how entrepreneuers prepare fresh tomatoes by cutting them 
into small pieces and drying them using solar driers to maintain the orginal taste. Also, the observations focused on the preparations of tomato wine, specifically, how it was bottled in different sizes and distributed to the consumers. Our observation strategy involved the researchers' participation in the lives of the women entrepreneurs under study in the field setting (Fetterman 1998).

Secondary data were collected from official reports, including reports on market challenges in Tanzania, which enabled the researchers to get insights about the governmental perspective on the issues affecting women entrepreneurs' business. The reports showed the development of women entrepreneurship in the study area, groups of women entrepreneurs dealing with food processing, efforts made by the government to enhance access market information through exhibitions, and strategies of SIDO as a government agency in the development of entrepreneurship domain. Furthermore, review of journal articles and books served as supportive background to the findings of our study.

The collected primary data were analyzed using conventional qualitative content analysis, in which the data were organized into categories and themes (Hsieh and Shannon 2005). Content analysis is an approach to the analysis of documents and texts that seeks to quantify the contents in terms of predetermined categories and in a systematic and replicable manner (Bryman 2012). The content analysis in this study followed this pattern: (i) appropriate texts for analysis were chosen (ii) the texts were spilt into smaller units of analysis (iii) relevant categories of analysis were developed (iv) coding of the units of analysis was done (v) analysis of the text in terms of the units and their relationship with other units that occurs in the text was done (Denscombe 2013).

\section{Results and discussion}

\section{Demographic characteristics}

Field data show that the entrepreneurial activities are highly influenced by age. This study quantified the demographic information into percentages in order to indicate their implications on women entrepreneurs to engage in food processing activities with respect to age, education and social problems. A total of 37 women entrepreneurs aged between 20 and 55 years involved in the food processing business were interviewed. Most of the interviewed women entrepreneurs (26 or $70 \%$ of participants) started doing business in their 20s. This concurs with the observations by some scholars that women start their business as young people between 20 and 30 years of age (Okafor and Mordi 2010; Marlow and Patton 2005).

With respect to the educational level of respondents, it is important to determine the qualification women entrepreneurs hold in their various processing activities. The findings revealed that the majority ( 31 or $83.7 \%$ ) of the interviewed women entrepreneurs had primary education as their highest level of education, while 4 (10.8\%) of the women had secondary education and only $2(5.4 \%)$ of the women had a Bachelor's degree level of education. During the focus group discussion with SARA group, the participants affirmed that "a large number of women entrepreneurs had limited chances to pursue formal learning beyond compulsory primary education because of cultural constraints embedded in the society". 
With respect to the three (3) key informants that participated in the study, they all were 35-44 years old females and had bachelor's degree level education with three or more years of work experience in their respective institutions.

\section{Motivation in business}

To address the question: What are the motivating factors for women to engage in entrepreneurial activities in the food processing business in Iringa? The results show that "engaging in business as a source of income" was the main motivating factor for entrepreneurship of the interviewed women during our study (Okuruf and Ama 2013). Another related aspect that was made visible during the data collection in this work was that involving themselves in business enabled women entrepreneurs to create their own job and "reduce dependency from family members". This goes in line with previously reported work of Jamali (2009) who also found that, the pursuit of financial independence motivated women entrepreneurs to engage in business in order to take control of their life and career. Women entrepreneurs in the FGDs with SARA group pointed out that "earning from business is used to improve their wellbeing by building modern houses, access to better diet, medical services, and pay school fees for their children and relatives". The money obtained from business enable women entrepreneurs to provide support for covering the basic needs in their household and improve life status. These findings also support the observations made by Datta and Gailey (2012) that women were motivated to engage in entrepreneurial activity because they earn income that enable them to provide good education to their children.

Furthermore, another interesting and less known aspect that motivated the interviewed women entrepreneurs to initiate their business was "to reduce wastage of farm products by drying" crops such as tomatoes, vegetables, and mushroom, hence adding value to the products through processing them into another form. Also, one of the key informants, the head of MUVI, pointed out that "the use of new technology for drying farm products using solar power also seems to attract more women entrepreneurs to engage in business". It was noted that the majority of respondent agreed that "the processing of food product added value to the price of the commodity". Simple processing such as sun-drying allowed the entrepreneurs to preserve perishable products for future consumption while retaining the original taste of the produce. In this way, the entrepreneurs boosted the value of their handled produced since dried products can be sold more expensively than their fresh counterpart, at the same time reducing the wastage of products. The promotion of using solar technology in the processing of different food products should be encouraged since in the developing countries are geographically located for optimal absorption of the sun's rays hence there is a big potential of solar energy if it is effectively harnessed (Foroudastan and Dees 2006). The solar technologies used in drying food products are simple to use and affordable to women entrepreneurs.

\section{Food processing activities}

According to researchers' observations during the field work, the processing activities are undertaken by groups or individual women entrepreneurs. Women entrepreneurs deal with more than one food product chain lines in order to diversify their activities 
and maximize profit. The food products processed include honey making, sunflower oil milling, tomato sauce and tomato wine making, tomato, mushrooms and other vegetable drying, spices, peanut butter and nutritious food including soya-beans flour.

The food processing by women entrepreneurs was noted to be "in a small scale because of poor processing tools, lack of reliable market and lack of enough capital to grow and sustain their business". In the FGDs the respondents reported that, "these obstacles pose high hurdles in our business resulting in low production and low product quality to fulfill the needs of customers". Improvement of processing tools, access to market, and capital seems to be a solution to increasing the quantity and quality of the products in order to meet the demand of the growing market.

\section{Women activities and time management}

It seemed that women entrepreneurs had double roles in the household, that is, as a mother and as breadwinner. The interviewed women argued that "We are responsible for handling domestic activities in order to upkeep our families". They woke up early in the morning for cleaning, fetching water and preparing breakfast for the family members. Upon completion of all domestic activities, they continued with food processing activities until late noon when they went back home to prepare meals. During evening hours, women proceeded with business activities. Women entrepreneurs seemed to manage their time properly by dividing time for domestic and business activities. The adherence to time schedule enabled them to handle double roles of domestic and food processing activities. One of the respondents emphasized that "we have to handle all duties in order maintain our families and make our business grow". This goes in line with previously published work on the unequal household power relations and responsibilities, falling mainly on the female due to socio-culturally defined roles (Brush et al. 2009).

\section{Source of business fund}

It was observed that women entrepreneurs acquired their initial capital for starting a business from various financial institutions. The majority of the participants obtained their capital from official financial institutions while few of them did so from individual sources. This is a new and interesting perspective related to women entrepreneurs in the food processing business as previous literature has pointed out that women SMEs from rural areas "fear to face FIs (financial institutions) for loans" (Majenga and Mashenene 2015). Servings and Credits Corporative Society (SACCOS) and local banks provided loans to women entrepreneurs upon submission of business plans and their security. During the focus group discussions, women entrepreneurs pointed out that "we get a small amount of loans as we were limited by the financial capacity to borrow more from the financial institutions". The collateral for women who are doing business in a group was their contributions in terms of shares, while individual women entrepreneurs had to surrender some of their fixed properties like a piece of land, house or animals, although this has to be approved by the Village Executive Officer (VEO) or any other leaders authorized by the village. This is contrary to previously reported work as in the study of Kumar et al. (2013) who reported that a Grameen bank in Bangladesh had reverse conservative 
banking practice by removing the need for collateral and created a banking system based on mutual trust, accountability, participation and creativity.

Another source of business fund for women entrepreneurs was personal savings or individual member's contributions from existing business activities. During the focus group discussion (FGD) with SARA group, it was revealed that, "in the new project of butter making it was funded 100\% from member's contributions as initial capital". The contributions made from individual members were used as capital to start another business for the group members. In the FGDs with SARA group, the study revealed that "women entrepreneurs contributed from their own sources to start processing peanut butter" which indicates that, they had limited access to official financial institutions for acquiring loans. Limited access to loans from FIs, makes women entrepreneurs to find an alternative source to finance their business projects with the aim of expanding and starting new business. There is need to reverse conservative banking practice by removing collateral and creating the system based on mutual trust between a customer and the bank.

\section{Women entrepreneurs and training}

The financial institutions provide training to women entrepreneurs on business plan writing, business record keeping, and business management before they acquire loans. However, the training does not suffice the needs for business improvement since the women lack skills in food processing. The training provided is elementary, which enables them to obtain the basic skills in business management. It was noted that, over $60 \%$ of women who participated in FGDs had attended training conducted by SACCOS at Nduli village on business plan writing and on how to repay back the loan. This training is a pre-requisite to obtaining the loan. The training was not adequate enough to address the women entrepreneurs' needs for growth as it aimed at elementary skills in business management. Access to suitable education and training would enable women entrepreneurs to obtain necessary skills and knowledge for business improvements, hence reducing gender inequalities in education.

\section{Socio- cultural challenges}

To address the research question: What are the socio-cultural challenges that affect business activities of women entrepreneurs in the food processing industry of Iringa? It was found that women entrepreneurs face several challenges in the processing of food products which includes: poor food processing technology, lack of access to suitable education and training, access to capital, and patriarchal ideology. It has been stated that women who work in entrepreneurial activities dominated by males, face unique challenges that differ from those who work in more gender balanced dominated activities (Martin and Banaras 2013).

Drawing from the institutional theory standpoint, it is evident that the results of the data analysis through the normative, cognitive and regulatory issues that create environmental obstacles to the development of women entrepreneurs of the study. Institutional theory gives insights by shedding light on the following aspects:

i. Regulatory barriers (RB) suggest that lack of access to markets, capital, packaging material and poor food processing technology make it difficult for women 
entrepreneurs to process food products in large volume, high quality and meet required international standards.

ii. Normative barriers (NB) suggest that due to unequal distribution of responsibilities in the household, women are shouldered with multiple responsibilities of taking care the family and doing business, hence it becomes difficult for them to engage fully in business activities.

iii. Cognitive barriers (CB) suggest that lack of access to suitable education and training in the childhood make it difficult for women to produce good quality products and realize competitive advantage in the free market economy.

Furthermore, in this work, feminist theories also provide insights and reflect on the analyzed data by shedding light on the following propositions:

i. From the socialist feminism perspective, changes toward equality in the education system could enable women to acquire necessary skills and engage fully in business activities on equal grounds as their male counterparts.

ii. From the liberal feminism perspective, women are disadvantaged relative to men due to overt discrimination that deprive them in accessing vital resources in business education and experience. Hence, the elimination of gender stratification, laws and cultural norms that limit women to access income, market and education that inhibits the business development of women entrepreneurs is of vital important to realize gender equality.

Figure 1 summarizes the socio-cultural challenges that this study revealed from the institutional and feminist theory perspectives within different levels of institutional structures alongside the transversal strategies that they use to tackle the issues.

\section{Regulatory barriers}

\section{Women entrepreneurs and access to market}

The market for women entrepreneurs' products was noted to be a big problem that prohibits them from expanding their business. It was revealed that, less than $20 \%$ of the interviewed women entrepreneurs had access to market during farmers' exhibitions once per year, whereby over $80 \%$ had never been exposed outside their locality, hence they had limited to none access to market information. The local market was saturated to absorb the products produced by women entrepreneurs since they produced more than what was being purchased. They had not expanded their market outside their region and country. The small sizeable market prohibited women from produce more since they are not sure whether they will find customers. Evidence from the study of Belwal et al. (2012) reveals that the unavailability of the suitable marketplace for products is an obstacle that faces women to acquire market-related skills. Furthermore, Ali and Ali (2013) are of the view that women entrepreneurs require confidence, leadership and managerial skills in access to the new market. Women need to get professional advice to start a business and find an attractive market (Belwal et al. 2012). The expansion of business networks is important to enhance the market for their products. 


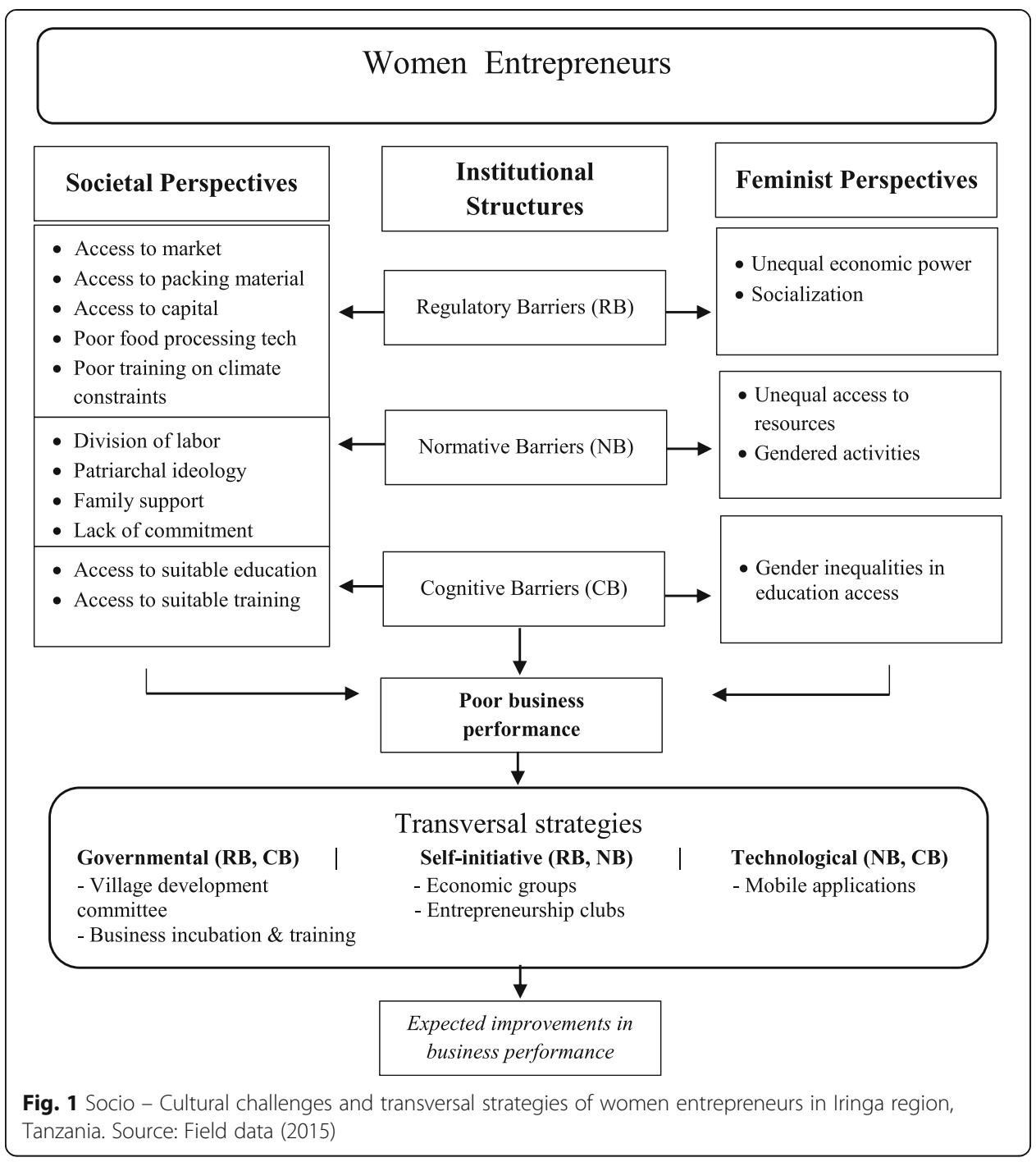

Furthermore, the study found that "lack of a permanent building for doing business contributes to the problem of market accessibility whereby customers fail to find them with their products". It was noted through FGDs that the women entrepreneurs do not have a specific and permanent building structures in which to sell their products. Due to the absence of a permanent market place, women tend to move carrying few products with them, looking for customers without knowing whether they will meet them. Women entrepreneurs tend to move in those areas where there is congestion of people like bus stand, and around big shops as they could chance to sell their products. However, this does not guarantee them to meet customers.

\section{Women entrepreneurs and access to packaging material}

The study observed further that, the supply of affordable packaging materials poses another threat to the growth of women entrepreneurs. The majority of responded argued that "packaging materials hinder the business development". Packaging materials were not available locally; hence they had to be imported from neighboring countries, 
making their price high and not easily affordable. Furthermore, it was noted that some of the packaging materials did not meet the required standards of Tanzania Bureau of Standard (TBS) and Tanzania Food and Drug Authority (TFDA) for certification in order to compete in the international market. Hence, poor packaging materials posed a problem for marketing their product and expanding their customers' base. For example, they stated that "when packaging honey, we re-used plastic bottle used to pack sunflower oil when we fail to get new bottles due to its price and unavailability". This is certainly detrimental to the product's taste and quality. A good packaging of food products is a strategy of attracting more customers to buy a product as it creates confidence to the consumers that the product is of high quality. Improvement of packaging materials would guarantee women entrepreneurs to increase their market size by selling more in wider geographical area.

\section{Women entrepreneurs and financial institutions}

Women entrepreneurs faced a challenge of availability of enough capital to invest and promote the existing business. In the two FGDs with SARA and MATUMAINI, the groups with 7 and 8 members respectively, the participants reported that "the loans obtained from SACCOS were small for investing in business". Lack of enough capital contributed to the failure of women's plans to improve their business. The work of Wasihun and Paul (2010) found that the major difficulty for entrepreneurs, especially for women, is access to credit because of the collateral requirement by the banks. The absence of microfinance institutions that enable them to access finance is the major obstacle for women to start a business (Wasihun and Paul 2010). It is clear that lack of access to initial capital and financial support or under-capitalization were perceived by most of the women entrepreneurs was and still is a problem (Jamali 2009). In their study, Magesa et al. (2013) asserted that access to collateral and asset based lending is a constraint to women from accessing finance because of strong cultural norms whereby women are not entitled to the assets. Women entrepreneurs in SSA do not have property in their names to use them as collateral for obtaining loans from financial institutions and other external sources (Singal 2009). Also, women entrepreneurs are confronted with rigid eligibility criteria in accessing financial services, which included having a registered business, trading license, and business plan, hence loan application process is so bureaucratic and stressful that many applicants give up before completing the process (Okuruf and Ama 2013).

Financial institutions provide an equal chance to access financial service for both male and female, but collateral becomes a constraint to women in accessing loans. This is contrary to the work of Belwal et al. (2012) where it was asserted that, in the emerging economies, banking and financial institutions differentiated between female and male for disbursement and sanctions of loans and rated women entrepreneurs inferior. In Tanzania, however, women entrepreneurs can manage to get few loans, but the interest rate is so high that it discourages them to borrow more money. For example, in Iringa region, women entrepreneurs who are in a registered group of 10-25 members may request for a loan of a maximum of four million Tanzanian shillings from SACCOS (managed by Iringa Municipal), repayable at the interest rate of $10 \%$ per year. The challenge of capital has contributed to cultural values which limit women to access the ownership of property, notwithstanding the government has passed laws which promote equality in the ownership of properties. 


\section{Women entrepreneurs and food processing technology}

The technology of food processing was noted to be still poor to the extent that it did not enable women entrepreneurs to produce good quality products. For example, at Nduli Village, it was observed that there was "one old milling machine of sunflower oil" which produces a poor quality product. The use of rudimentary tools hinders them to process food products in large volume and with high quality in order to cater the market needs. All the three interviewed groups of women in the FGDs complained that "the tools we uses, pushes back our efforts to empower ourselves from poverty alleviation, as we spend many hours and great effort just to produce little". Furthermore, women lacked knowledge of food processing despite the fact that they had attended a basic training program conducted by SIDO. It was also noted that processing place pose more difficulties to produce quality products as required by the Tanzania bureau of standards (TBS) and Tanzania Food and Drug Authority (TFDA) for certification. Women entrepreneurs process food products at their own residence, risking contamination with other impurities. To process a food product it requires a well-designed space, high level of knowledge and skills so as to produce more products with high quality in order to gain a competitive advantage in the market as it required by TBS.

\section{Women entrepreneurs and weather climatic changes}

The change of weather climate affected the growth of the women entrepreneurs business. The study revealed that unreliable rainfall affected the availability of honey in Nduli village. Rainfall helps in the growth of vegetative flowers that the honey bees of the region use. Hence, the absence of enough rainfall to support the growth of vegetative flower affects the availability of honey and other products. Honey is a natural product which is harvested from the beehives, put by women entrepreneurs in forested areas. One of the respondents pointed out that "unreliable and seasonal rainfall affects the quantity of honey to satisfy the demand of customers due to its importance in Tanzanian society as food as well as medicine". Also, it was noted that unreliable rainfall affects the growth of other crops like sunflower and tomato that are used as raw materials for processing into various farm products. The presence of reliable meteorology stations is then of paramount importance in order to forecast climatic changes and informing women entrepreneurs about the right time to undertake agricultural activities. The government should also employ the expertise of agriculture in order to disseminate information on the best agricultural practices.

\section{Normative barriers}

\section{Women entrepreneurs and division of labor}

During this study, it was observed that there was an unequal distribution of responsibilities between women and their male counterpart in the household. Women take care of children, what they eat, wear, and other upkeep necessary for them as basic needs. Women entrepreneurs involved in the study stated that "household responsibilities is one of the main barriers in business". Women entrepreneurs were responsible for taking care of the households and at the same time engage in food processing as a means to earn income for family members. This observation is also supported by studies carried out by Amine and Staub (2009), Huyer and Sikoska (2003), Ihugba and Njoku (2014), 
and Jagero and Kushoka (2011) who observed that women's responsibilities in the household were barriers in women's business development. The work of Jamali (2009) also asserted that women faced disapproving remarks from their family and husband, pointing out that in society, it was probably imprudent for a husband to let his wife work, this was seen as a sign of his inability to support his family. Woman entrepreneur, furthermore, may be perceived negatively as someone dedicating more time to her job than her family. The work of Belwal et al. (2012) revealed that family responsibility, household obligations and lack of social support constrained women entrepreneurs in confronting challenges imposed by the external business environment, hence entrepreneurship is a forced choice arising out of emergent family responsibility rather than ambition. The cultural environment of Tanzania makes it more difficult for women to start and run enterprises due to the expectations of their traditional reproductive roles (ILO 2002; Jagero and Kushoka 2011). Women entrepreneurs reported salient normative constraints, stemming from the ascription of women to traditional family roles, the ascription of males to bread winner roles, and the primacy of family life and child-care responsibilities (Jamali 2009). Therefore, women have more social constrains to the extent that hinders the growth and expansion of their business.

\section{Women entrepreneurs and family support}

Little support from their male counterparts was another challenge encountered by women entrepreneurs. Women were struggling with themselves to initiate and improve business whereby men did not put emphasis to support them. In the FGDs, one of respondents observed that "family separation caused by men to restrict their wives not to engage in business is a common practice in Iringa Region as a result it frustrates women entrepreneurs from doing business". Our study controverts with Jamali (2009) who found that women entrepreneurs get support from relatives by providing them with the initial fund for investing in business. Our study suggests that we need more training in the society on eliminating a negative ideology towards women entrepreneurs. Women entrepreneurs need to be involved in the national development agenda as they play a vital role in the economic development of the society and nation at large. The strategy of involving women in the development agenda has to start from the grass root level (i.e. at the level of family), by supporting initiatives of women in entrepreneurship activity.

\section{Women entrepreneurs and social attitude}

The society's perception towards women entrepreneurs was found to be dominated by patriarchy ideology, whereby ownership of business activity was entitled to men. In Africa a woman who handles money is often inferred to have gotten her funds through the sexual work (Scott et al. 2012). Women who are doing business are normally perceived to be untruthful in the household as they interact with outsider men in the course of doing business. During an in-depth interview with SIDO manager, it was stated that "the negative attitude toward women entrepreneurs discourages them from doing business effectively as many decide not to engage in business in order to maintain their marriage". Furthermore, in the FGD with SARA group asserted that "the society perceives that in the household if wealth is owned by women entrepreneurs it implies that men have no control over their families and they would be dictated by their wives". 
Negative ideology in the families towards women entrepreneurs, tend to push back development at the household level. Joint efforts between men and women in doing business at the family level is of great important in improving wellbeing, hence elimination of negative attitude towards women entrepreneurs doing business.

\section{Women entrepreneurs and divided loyalty}

Lack of commitment of the group members creates a barrier to the development of their business. Women entrepreneurs tended to be loyal to their personal business an aspect which contributes to the failure of joint (group) business in terms of producing large volume and high quality products. The women entrepreneurs who work individually tend to be more committed to their business as opposed to those who works with the group. In the FGDs with SARA group, one of the respondents said, "some of the members concentrate more on their personal business rather than group business activities". Therefore the commitment of members is an important aspect in the success of group business activity as they put efforts and resources together to produce in large volume with less time spent in processing activities.

\section{Cognitive barriers}

\section{Women entrepreneurs and educational opportunities}

The study shows that women entrepreneurs lack education since the majority (over $80 \%$ ) had completed compulsory primary education. It was noted that "most of the women entrepreneurs' family tend to give also education to girls which enable them to engage fully in developing business during their adulthood". Gender discrimination in the emerging economies demonstrated in socio-cultural practice in terms of access to education opportunities between boys and girls (Yusuf 2013). Amine and Staub (2009) argued that inadequate education leaves women ill-equipped to resist normative pressures from society that ask for them to conform to traditional social role's expectations for the division of labor. Therefore, functional training is required to impart women entrepreneurs with the necessary skills and knowledge to improve their business as to realize competitive advantage in this era of free market economy. Training on financial record keeping, marketing skills and processing of products could be vital for women entrepreneurs to flourish in their businesses and compete on equal footing with a male counterpart.

These challenges are similar to many of the already reported studies. However, this study contributes on schematizing the strategies that women use to improve business development and empowering themselves in order to participate fully on equal footing with their counterpart male entrepreneurs. The transversal strategies created by women entrepreneurs play vital roles in mitigating challenges that confront them in the course of doing businesses.

\section{Transversal strategies}

To address the research question how can these challenges be mitigated or addressed to satisfaction in order to promote the continuing growth of the region and the empowerment of women in society?, we looked into the strategies that the women entrepreneurs of the region employ in order to tackle the socio-cultural issues that they face. This 
work unveiled several transversal strategies used by women entrepreneurs in Iringa. These strategies are referred herein as transversal because they are effectively applied to a wide-range of situations and contexts. Fieldwork shows two different kinds of transversal strategies that seemed to benefit women entrepreneurs: those created for the women entrepreneurs by governmental institutions and those strategies created by the women entrepreneurs themselves. Furthermore, we consider the application of mobile technology as a transversal strategy that tackles the regulatory, normative and cognitive barriers that hinder women entrepreneurship sustainable development.

One of the transversal strategies which could be employed by the women entrepreneurs is mobile technology application which would enable women entrepreneurs to access market information and expansion of business networks (RB). This type of mobile technology application would enable women entrepreneurs to make business at their own pace while maintaining the welfare of the family and complying with societal roles and expectations of the society in Tanzania (NB). Furthermore, a contextualized application developed taking into consideration the levels of literacy of the end-users (e.g., women entrepreneurs and their customers) could provide another source of empowerment through easy accessibility and usage (CB) from the governmental initiative to the self-created ones. A description of mobile technology as a transversal strategy is also given below.

\section{Transversal strategies created by the government}

These strategies aim to tackle regulatory (e.g., access to capital, unequal economic power, etc.) and cognitive (e.g., inequalities in education access) barriers that hinder women entrepreneurs in the development of their business activities.

\section{Village development committee}

Extension of finance services to the rural community by the government through village development committee has made available the access to capital for a start-up business. The main targeted group of the development committee policies is women entrepreneurs doing entrepreneurial activities. The strategy of extending financial services close to the villagers enables women entrepreneurs to acquire loans at lowinterest rate with minimal collateral conditions, although the capital is generally a very small amount, which does not suffice the needs entirely because of high demand. Nevertheless, this has been a solution for women entrepreneurs who cannot access finance from banks where interest rates are high and collateral conditions are strict. Access to loan through village development committee serves as an effective weapon to fight cultural constraints and enhance the development of entrepreneurship of the women who have been kept outside the banking orbit due to their poor income (Kumar et al. 2013). There is need to set aside more funds by the government and direct close to the villagers through development committee.

\section{Business incubation and training}

Business incubation (BI) provides functional training in the area of marketing, record keeping, financial management, processing and packaging of food products. Business incubators serve as learning ground for women entrepreneurs in acquiring skills 
necessary to engage in business. The presence of business incubator operating under the umbrella of the Small Industrial Development Organization (SIDO), enables women entrepreneurs to acquire the necessary business skills and education that they may lack due to cultural constraints. Furthermore, incubators also offer extension services that offer women entrepreneurs advise on business management. Nevertheless, the existing incubators are urban- based, neglecting those operating their business in the rural areas. Training provided in the incubators are practical oriented which accommodate all a participants regardless the level of education.

\section{Transversal strategies created by the women entrepreneurs}

These strategies tackle regulatory (e.g., access to capital, food processing technology) and normative (e.g., unequal access to resources) barriers that women entrepreneurs face.

\section{Economic groups}

The joining of economic groups constitutes another innovative transversal strategy adopted by women where the members put their efforts together in order to enhance entrepreneurship development. Women entrepreneurs who are working jointly in economic groups guarantee themselves to acquire loans from microfinance institutions, by using the group as guarantor. In other words, in case that one of the group members default, the rest of the members can assume responsibilities for the left member's share. Therefore, this strategy of working in economic groups is a panacea to socio-cultural constraints of getting finance for business development and finally support family wellbeing (e.g., paying school fees for their children, etc.). Furthermore, it enable, women entrepreneurs to tackle other challenges, for instance, food processing technology, packaging materials, access to resources, unequal economic power, inequality in education hence results into enhancing women power to participate in decision making in the household and higher organs. Therefore, working in economic groups in an innovative strategy of developing women entrepreneurship by eliminating challenges embedded in socio-cultural perspective and create a conducive environment for doing business as their counterpart male entrepreneurs.

\section{Entrepreneurship clubs}

Another transversal strategy that we noticed during our fieldwork was the formation of women's entrepreneurship clubs where members can discuss constraints of business development in different environmental contexts. Clubs enable to identify critical sociocultural issues and come up with a solution which ties to a given society. The extent and magnitude of the challenges facing women differ depending on the context of a given society or country where they operate their businesses. Therefore, the creation of women's entrepreneurship clubs could be applied to different environmental background, approaching the challenges facing women entrepreneurs from a different dimension in a given society in the development of entrepreneurship.

\section{Transversal strategy offered by technology usage}

The widespread use of mobile devices provided an opportunity to design solutions that are portable and easily adopted by the users. During our fieldwork, we noticed that all 
the observed participants rely on mobile phone technology to carry out their daily communications with family and friends. However, our previous research showed that women entrepreneurs in rural area are not using mobile phone technologies to their full potential (Kapinga et al. 2016).

Mobile technology has been shown to enable women entrepreneurs to establish a link with customers at their own business premises (Munyua and Mureithi 2008). Furthermore, the phones can enable women to build investment capital as a result of bulk marketing and to know the price of produce in various market places (Masuki et al. 2010). Hence, phone usage in business can serve as a strategic marketing tool to improve business performance. Moreover, mobile phone usage is important to women entrepreneurs since it can also enable them to search information, improve communication with lenders, suppliers, customers, colleagues and trainers at any time anywhere, saving time for other responsibilities (Donner and Escobari 2009). Since it has been shown that marketing strategies improve the performance of women enterprises (Ewere et al. 2015) applying mobile technology to enhance women entrepreneurs' business ventures visibility in the market is a promising intervention.

Therefore, it is argued that using mobile phone technology as a tool to tackle regulatory barriers, particularly in the area of access to market information, provides a plausible solution. Furthermore, a mobile phone based intervention could be ideal in addressing normative barriers whereby women entrepreneurs could access better market while still participating in their social responsibilities. Cognitive barriers could also be addressed by providing the users with brief, accessible training tips on how to handle and promote their business. A mobile phone application designed for these purposes can enable the user to access market information on potential customers, prices, demand of goods and reduce traveling expenses to the market place. Moreover, the application could enable women to engage in both productive and reproductive roles while maintaining good relations in the household. Such an intervention could take advantage of the widely spread use of mobile phones in developing countries - in Tanzania the number of mobile phone subscribers has increased enormously, providing opportunities for its use in business activities.

\section{Conclusions and future research}

This study calls for educational and governmental programme solutions in order to bring a gender-neutral participation in business activities between the sexes. The programme should be designed to bridge the gender gap on equal access to business opportunities by addressing gendered self-efficacy and self-confidence. Also, this study calls for the need of changing society's mindset about the social constructed roles and ownership of property that would enable women to participate on equal footing with men in business activities and to contribute to economic development from the household level to the national level at large. Therefore, understanding these constraints through institutional and feminist theories could play an important role in bringing gender equality and entrepreneurship development.

The experience gained during our field study form the groundwork for giving recommendations on meliorating the socio-cultural challenges facing women entrepreneurs and on how mobile phones could assist to tackle them. Hence, the following recommendations are put forward: 
i. Education in society is of paramount importance of eliminating the negative ideology on the role of women's participation in the economic development of the household and the nation at large. Women should participate equally in the national economic development agenda.

ii. Enforcement of free educational policy in primary and secondary schools about equality in enrollment between sexes by the government is of vital importance in empowering girls in adulthood when engaging in business activity in Tanzania. Implementation of this policy depends on the political will of government officials to enforce the policy by means of laws and regulations in creating a women friendly user environment to voice their opinions and concerns. Education to girls should be given priority in the development agenda. This would enable them to participate equally in entrepreneurship development during adulthood and influence decision making organs in favor of women and minorities.

iii. Educational development of women entrepreneurs requires the facilitation of comprehensive training in the area of production innovation, marketing strategy, business record keeping and financial management in order to improve business.

iv. The usage and application of mobile phone technology based sustainable interventions to address the challenges facing women entrepreneurs are of vital importance. The use of mobile technology would enable women to expand business networks to various stakeholder hence improvements of their business and receive necessary market information for making a sound business decisions about where to sell their products at high prices. The government and other stakeholders should educate women entrepreneurs on the importance of applying mobile technology-based services to enhance their business while handling family responsibility at their own pace.

This study has various limitations. First, it focused only on women entrepreneurs in food processing in Iringa, small sample size of the study is unescapable. The second limitation is that it dealt with only women entrepreneurs in food processing. Those working in different business chains were not included.

In spite of these limitations, this study sets a baseline for future research opportunities. This study focused on exploring the challenges facing women entrepreneurs, hence further research on comparative analysis about the challenges facing both women and men entrepreneurs in the same environmental setting in order to establish whether they face the same or not. In addition, further study may want to investigate additional variables that exert a fundamental influence on women's business development.

In conclusion, this study strived to widen the understanding of women's business by exploring socio-cultural challenges facing women entrepreneurs in Iringa, Tanzania. The findings of this study have shown that women entrepreneurs are motivated to engage in the business in order to improve their household income and employ themselves in the informal sector as well as to raise their family's life standards and improve the financial position in their household. Furthermore, the field work showed that women entrepreneurs added value to their farm products by processing them and helped each other on social matters, which prompted more women to engage in business activities.

It has been revealed by this study that women entrepreneurs operated in an unfavorable socio-cultural environment which was characterized by unequal distribution of 
social responsibility, inadequate education, and patriarchal ideology, poor quality of products, inadequate capital and the unreliable market for the produced goods. These problems prohibit women entrepreneurs to realize higher profits and expand business networks in other regions and outside the country. Women entrepreneurs were found more at a disadvantaged position as they faced more challenges as compared to their male counterparts since they had to also handle family responsibilities entirely while doing small businesses.

With the proliferation of mobile phone technologies in the developing countries, there is an opportunity to employ them in the business arena as a means of confronting socio-cultural challenges facing women entrepreneurs. In particular, this study puts forward an intervention to address the problem of accessing market information through a mobile phone application in order to enable women to handle family matters and conducting business activity uninterrupted. Future work will be geared towards the holistic evaluation and validation of such an intervention.

\section{Endnote}

${ }^{1}$ Union of Village Entrepreneurs, in English

\section{Acknowledgements}

We want to thank the College of Business Education (CBE) for their support of this research project. Also, we thank the journal reviewers for their strong recommendations for improving the manuscript.

\section{Funding}

This paper is part of PhD programme at the University of Eastern Finland with the collaboration of College of Business Education, Tanzania. I declare that the source of Fund is College of Business Education (CBE), Tanzania in the design, data collection and interpretation of the results. It is part of student sponsorship allowance which covers to include article writing.

\section{Authors' contributions}

AFK is the main author of this paper (student at the University of Eastern Finland) He contributed more than the other authors of the manuscript. CSM is the main supervisor and the main guider in writing the manuscript. All authors have contributed in the preparation of the manuscript submitted to the Journal of Global Entrepreneurship Research. Both authors read and approved the final manuscript.

Authors' information

Calkin Suero Montero (PhD), Senior Researcher at the School of Computing, University of Eastern Finland. She supervise PhD candidate at the edtech Hubbased at the College of Business Education, Dar es Salaam, Tanzania. Contact phone $+358,504,423,789$.

Competing interests

The authors declare that they have no competing interests.

\section{Publisher's Note}

Springer Nature remains neutral with regard to jurisdictional claims in published maps and institutional affiliations.

\section{Author details}

${ }^{1}$ College of Business Education (CBE), Dar es Salaam, Tanzania. ${ }^{2}$ School of Computing, University of Eastern Finland, Dar es Salaam, Tanzania.

Received: 27 March 2017 Accepted: 2 August 2017

Published online: 14 August 2017

References

Ali, A. H., \& Ali, A. Y. (2013). Challenges and constraints faced by Somali women entrepreneurs in Benadir region. Interdisciplinary J Contemp Res Bus, 5(2), 436-411.

Amine, L. S., \& Staub, K. M. (2009). Women entrepreneurs in sub-Saharan Africa: An institutional theory analysis from social marketing point of wiew. Entrep Reg Dev, 21(2), 183-211.

ASSP. (2014). Agriculture statistics strategic plan( 2014/15-2018/19),national team 2014. Retrieved from www.nbs.go.tz/ nbs/takwimu/Agriculture/Agriculture_statistics_strategic_plan2014-15_2018-19.pdf

Audretsch, D. B., Grilo, I., \& Thurik, A. R. (2007). Handbook of research on entrepreneurship policy. UK: Edward Elgar Publishing, inc.. 
Baron, R. A. (2013). Enhancing entrepreneurial excellence: Tool for making the possible real. UK: Edward Elgar Publishing, Inc.

Belwal, R., Tamiru, M., \& Singh, G. (2012). Microfinance and sustained economic improvement:Women small scale entrepreneurs in Ethiopia. Journal of International Development, 24(S1).

Brush, C. G., De Bruin, A., \& Welter, F. (2009). A gender-aware framework for women's entrepreneurship. Inter J Gender Entrep, 1(1), 8-24.

Bryman, A. (2012). Social research methods. New York: Oxford University Press.

Cresswell, J. W. (2014). Research design:Qualitative,Quantitative and mixed methods approaches (4th ed.). Uk: SAGE Publications.

Datta, P. B., \& Gailey, R. (2012). Empowering women through social entrepreneurship: Case study of a women's cooperative in India. Entrepreneurship Theory and Practice, 36(3), 569-587.

Deakins, D., \& Freel, M. (2009). Entrepreneurship and small firms (5th ed.). New York: McGraw-Hill.

Denscombe, M. (2013). The good research guide: For small-scale social research projects. New York: Open University Press.

Donner, J., \& Escobari, M. (2009). A review of the research on mobile use by micro and small enterprise(SMES). International Conference on Information and Communication Technologies and Development (ICTD), 2009 International Conference on (pp. 17-26). IEEE.

Eddleston, K. A., Kellermanns, F. W., \& Zellweger, T. M. (2012). Exploring the entrepreneurial behaviour of family firms: Does the stewardship perspective explain differences? J Entrep Theory Pract, 36(2), 347-367.

Ewere, A. D., Adu, E. O., \& Ibrahim, S. I. (2015). Strategies adopted by women entrepreneurs to ensure small business success in the Nkonkobe municipality, eastern cape. Journal of Economics, 6(1), 1-7.

Fetterman, D. M. (1998). Ethnographic: Step by step. Thousand. Oaks: CA, Sage.

Fischer, E. M., Reuber, A. R., \& Dyke, L. S. (1993). A theoretical overview and extension of research on sex, gender and entrepreneurship. Journal of Business Venturing, 8(2), 151-168.

Flick, U. (2009). An introduction to qualitative research. London: SAGE Publications Ltd.

Foroudastan, S. D., \& Dees, O. (2006). Solar power and Sustainability in developing countries. proceeding of International Conference on renewable energy for developing countries, (pp. 1-13).

Gichuki, C. N., Mulu-Mutuki, M., \& Kinuthia, L. N. (2014). Performance of women owned entreprises accessing credit from village credit and savings associations in Kenya. J Glob Entrep Res, 4(1), 16.

Gliner, J. A., Morgan, G. A., \& Leech, N. L. (2009). Research methods in applied setting: An integrated approach to design and analysis. New York: Routledge, Taylor and Francis group.

Gorji, M. B., \& Rahimian, P. (2011). The study of barriers to entrepreneurship in men and women. Aust J Bus Manage Res, 1(9), 31-36.

Greer, M., Greene, P. G., \& Butler, J. E. (2003). Feminist theory and the study of entrepreneurship:In new perspectives on women entrepreneurs, Research in entrepreneurship and management. Greenwich: Information Age Publishing.

Hisrich, R. D., \& Peters, M. P. (2002). Entrepreneurship (5th ed.). New Delhi: McGraw-Hill.

Hsieh, H. F., \& Shannon, S. E. (2005). Three approaches to qualitative content analysis. Qualitative Health Research, 15(9), 1277-1288.

Huyer, S., \& Sikoska, T. (2003). Overcoming the Gender Digital Divide:Understanding ICT nad their potential for the women empowerment. INSTRAW RESEARCH PAPER SERIES NO 1.

Ihugba, O. A., \& Njoku, A. C. (2014). Theoretical analysis of entrepreneurship challenges and prospects in Nigeria. Int Lett Soc Humanistic Sci, 5, 21-34.

ILO. (2002). Report on women entrepreneurship in Tanzania: Jobs;gender and small entreprise in Africa. Dar es salaam: University of Dar es salaam Entrepreneurship centre(UDEC).

Jagero, N., \& Kushoka, I. (2011). Challenges facing women micro entrepreneurs in Dar es salaam,Tanzania. Int J Human Resour Stud, 1(2), 1.

Jamali, D. (2009). Cosntraints and opportunities facing women entrepreneurs in developing countries: A relational perspective. Gender Manage, 24(4), 232-251.

Jennings, J. E., \& Brush, C. G. (2013). Research on women entrepreneurs: Challenges to (and from) the broader entrepreneurship literature? The Academy of Management Annals, 7(10), 663-715.

Kapinga, A. F., Montero, C. S., \& Mbise, E. R. (2016). Investigating women entrepreneurs usage of mobile technology for accessing market information in Iringa, Tanzania, International conference on interactive mobile communication, technologies and learning (IMCL) (pp. 73-77). San Diego: IEEE.

Kumar, D., Hossain, A., \& Gope, M. C. (2013). Role of micro-credit program in empowering rural women in Bangladesh. Asian Bus Rev, 3(4), 114-120.

Kuratko, D. (2011). Entrepreneurship:An introduction (8th ed.). New Delhi: South-western Cengage Learning.

Kutanis, R. O., \& Bayraktaroglu, S. (2003). Female entrepreneurs :Feminist insight for overcoming the barriers. Gender Perspactives and management. Turkey: Sakarya University.

Longenecker, J. G., Moore, C. W., \& Petty, J. W. (2003). Small business management:An entrepreneurial emphasis (12th ed.). USA: Thomson South-West.

Magesa, C., Shimba, C., \& Magombola, D. (2013). Investigating impediments towards access to financial services by women entrepreneurs: A case of Arumeru District. Dev Country Stud, 3(11), 105-115.

Majenga, A., \& Mashenene, R. G. (2015). Socio-cultural factors and financial performance among women small and medium enterprises in Tanzania. Eur J Bus Manage, 6(32), 153-163.

Marlow, S., \& Patton, D. (2005). All credit to men? Entrepreneurship, finance, and gender. Entrepreneurship Theory and Practice, 29(6), 717-735.

Martin, P., \& Banaras. (2013). The experience of women in male-dominated occupation: A constructive grounded theory inquiry. SA J Ind Pyschology, 29(2), 01-12.

Mashenene, R. G., Macha, J. G., \& Donge, L. (2014). Socio-cultural determinants of entrepreneurial capabilities among the Chagga and Sukuma small and medium enterprises in Tanzania. J Econ Sustainable Dev, 5(17), 90-103.

Masuki, K. F., Kamugisha, R., Mowo, J. G., Tanui, J., Tukahirwa, J., Mogoi, J., \& Adera, E. O. (2010). Role of mobile phones in improving communication and information delivery for agricultural development:Lesson from south western Uganda, ICT and development-research voice from Africa. International Federation for Information Processing (IFIP), technical commission 9-relationship between computers and society (pp. 1-14). Uganda: Makerere University. 
Maziku, P., Majenga, A., \& Mashenene, G. R. (2014). The effect of socio-cultural factors on the performance of women small and medium enterprises in Tanzania. J Econ Sustainable Dev, 5(21), 51-62.

Mmasa, J. J. (2013). Policy Brief No 8: Participation of women in Agriculture in Tanzania: Challenges and Policy Recommendations. Retrieved from www.clknet.or.tz/wp-content/uploads/2013/12/PB_20_Value-Addition-Practicesto-AgriculturalCommodities-in-Tanzania.pdf

Mordi, C., Singh, S., \& Okafor, C. (2010). The role of cultural values in understanding the challenges faced by female entrepreneurs in Nigeria: Gender in management. Int J, 125(1), 5-21.

Munyua, A. W., \& Mureithi, M. (2008). Harnessing the power of the cell phone by women entrepreneurs: New Frontiers in the gender equation in Kenya. Kenya: Grace Project Research.

Okafor, C., \& Mordi, C. (2010). Women entreprneurship development in Nigeria: The effect of environmental factors. Econ Sci Ser, LXII(4), 43-53.

Okuruf, F. N., \& Ama, N. O. (2013). Assessing factors that affect women and youth micro-entrepreneurs in Botswana. Int J Acad Res Econ Manage Sci, 2(1), 306-332.

Olomi, D. (2009). African entrepreneurship and small business development: Context and process. Otme Company Limited: Dar es Salaam.

Pines, A. D., Learner, M., \& Schwartz, D. (2010). Gender differences in entrepreneurship: Equality diversity and conclusion time of global crisis. Int J, 29(2), 186-198.

Rutashobya, L. K., \& Nchimbi, M. I. (1999). The African women entrepreneurship: knowledge gaps and priority areas for future research. African Entrepreneurship and Small business development.

Saunders, M., Lewis, P., \& Thornhill, A. (2009). Research methods for business students (5th ed.). Italy: Rotolito Lombarda.

Scott, L., Dolan, C., Johnstone-Louis, S., \& K., \& Wu, M. (2012). Enterprise and inequality: A study of Avon in South Africa. Entrepreneurship Theory and Practice, 543-568.

Scott, W. R. (2001). Institutions and organizations. Thousands Oaks: Sage.

Siddiqui, A. B. (2012). Problems enccountered by women entrepreneurs in India. International Journal of Applies Research and Studies, ISSN 2278-9480,Vol 1,Issue II, Sept-Nov,2012/189.

Singal, R. K. (2009). Entrepreneurship development and management. New Delhi: S.K.Kataria and Sons.

Singh, G., \& Belwal, R. (2008). Entrepreneurship and SMEs in Ethiopia: Evaluating the Role, prospects, and problems faced by women in this emergent sector: Gender in Management. Int J, 23(2), 120-136.

Storey, D. (1994). Understanding the small business sector. London: Routldge.

The United Republic of Tanzania (URT). (2015). Annual report for financial year 2014/2015. Dar es Salaam: Ministry of Agriculture, food security and cooperatives.

Vecian, J. M., \& Urbano, D. (2008). The Institutional approach to entrepreneurship research: Introduction. International Entrepreneurship Management Journal, 365-379.

Wasihun, R., \& Paul, I. (2010). Growth determinants of wwomen-operated micro and small enterprise in Adis Ababa. $J$ Sustainable Dev Africa, 12(6), 233-246.

Wetherly, P., \& Otter, D. (2011). The business environment (2nd ed.). USA: Oxford university press.

Woldie, A., \& Adersua, A. (2004). Female entrepreneurs in a transitional economy: Business women in Nigeria. International Journal of Social Economics, 31(1/2), 78-90.

Yusuf, L. (2013). Influence of gender and cultural beliefs on women entrepreneurs in developing economy. Sch J Bus Adm, 3(5), 117-119.

\section{Submit your manuscript to a SpringerOpen ${ }^{\circ}$ journal and benefit from:}

- Convenient online submission

- Rigorous peer review

Open access: articles freely available online

- High visibility within the field

Retaining the copyright to your article 